\title{
IMPROVING STUDENT'S MATHEMATICAL REASONING AND SELF CONCEPT BY USING RECIPROCAL TEACHING
}

\author{
Dani Agung Prasetio ${ }^{1}$, Utari Sumarmo², Asep Ikin Sugandi ${ }^{3}$ \\ ${ }^{1,2,3}$ Mathematics Education of Post Graduate IKIP Siliwangi, Cimahi \\ ${ }^{1}$ Daniagungp94@gmail.com, ${ }^{2}$ utari.sumarmo@gmail.com, 3asepikinsugandi@yahoo.co.id
}

Received: Sep 18 ${ }^{\text {th }}, 2018 ;$ Accepted: Sep $18^{\text {th }}, 2018$

\begin{abstract}
This study is a pretest-postest experiment control group design having a goal to analyze the role of Previous Mathematical Ability and Reciprocal Teaching in mathematics (RTM) on students' mathematical reasoning ability (MRA) and self concept in mathematics (SCM). The study involves 66 seventh grade students, a PMA test, a MRA test, and a SCM scale, and student's perception on RTM. The study revealed that RTM took better role than PMA on obtaining MRA and SCM. For entirely students and of students with high PMA in both teaching approaches and the grades of MRA and SCM were at high level. Besides that, study found there were no association between MRA and SCM and there were no interaction between PMA and teaching approaches toward RMA and SCM. Like that, students expressed positive opinion on RTM, even if, student still realized few difficulties in solving MRA,
\end{abstract}

Keyword: mathematical reasoning abilitty, self confidence, reciprocal teaching, perception on RTM

\begin{abstract}
Abstrak
Penelitian ini adalah suatu eksperimen dengan disain pretes-postes kelompok kontrol yang bertujuan menelaah peranan pengetahuan awal matematika (PAM) dan pembelajaran terbalik dalam matematika (PTM) terhadap kemampuan penalaran matematik (KPM) dan kepercayaan diri dalam matematik (KDM) siswa. Penelitian melibatkan 66 siswa kelas 7, tes objektif PMA, tes uraian KPM, dan skala KDM. Studi menemukan bahwa PAM beren terhadap pencapain dan peningkatkan KPM dan pencapain KDM. Secara keseluruhan dan pada siswa dengan PMA sedang dan rendah, mutu KPM dan $\mathrm{N}<\mathrm{G}>$ nya siswa yang mendapat PTM lebih baik dari pada mutu siswa yang mendapat pembelajaran konvensional. Demikian pula secara keseluruhan dan pada siswa dengan PMA sedang dan tinggi, mutu KDM siswa yang mendapat PTM lebih baik dari pada mutu KDM siswa yang mendapat pembelajarn konvensional. pada kedua kelas pembelajaran tergolong sedang dan mutu kemandirian belajar siswa Secra keseluruhan, mutu KPM dan KDM siswa tergolong baik. Selain itu, siswa menunjukkan pandangan yang positif terhadap PTM, dan siswa masih mengalami sedikit kesulitan dalam menyelesaikan soal-soal KPM, tidak terdapat interaksi antara PAM dan pembelajaran terhadap KPM dan KDM, dan tidak terdapat asosiasi antara KPM dan KDM,
\end{abstract}

Kata kunci: penalaran matematik, kepercayaan diri, pembelajaran terbalik

How to Cite: Prasetio, D.A., Sumarmo, U., \& Sugandi, A.I. (2018). Improving Student's Mathematical Reasoning and Self Concept by Using Reciprocal Teaching. JIML, 1 (3), 283294.

\section{INTRODUCTION}

Based on writers' limited observation when visited a mathematics lesson, we found two kinds students condition. First condition ilustrated that nearly students were competent to solve rutine mathematics problem without any difficulty. Even if, second condition pointed out that many student not able to test the truth of computation process, to prove mathematics expression, and to explain the rules used in solving mathematics problem. That second condition ilustrated limited student's capability on solving mathematical reasoning (MR) task. Whereas, MR was an essential mathematics 


\section{Prasetio, Sumarmo, \& Sugandi, Improving Student's Mathematical Reasoning and Self Concept by Using Reciprocal Teaching}

ability should be mastered by high school students. The last statement not only caused of MR was attached in the goal of mathematics teaching (NCTM, 2000), but also it was relevant to some mathematics experts' opinion. The goal and vision of teaching mathematics, among other were: to improve student's potency to become a critical, creative, logical, accurate, and innovative human. In addition, Barrody, A (1993) proposed that MRA was important ability and should be possessed by student caused of it helped student not only to memorize fact, rules, and steps of solving problem, but also to realize student to use relevant rules and principles in solving problem as well, so that student obtained meaningful mathematics understanding.

There were some experts' conception about MRA namely: a) MRA was to derive conclusion based on relevant data, event, facts, evidence, and or sources (Keraf, Shurter and Pierce, as cited in Hendriana, H., Rohaeti, E.E., Sumarmo (2014), Shadiq (2004); b) MR was reasoning about and with mathematics object (Brodie, 2010, Kusnandi, 2008, as cited in Hendriana, H., Rohaeti, E.E., Sumarmo (2014). To consider the mathematical process happened on solving MRA, it indicated that MRA was classified as higher order thinking (HOT) task in mathematics, that implied for solving MRA student should have high mathematics soft skill such as self concept in mathematics (SCM). Concerning teacher's role, Polya (1980), Glasersfeld and Nickson as cited in Suparno (1997) proposed that the role of teacher not only to deliver information but the more important things were: To act fit to student's condition, to understand student's thinking, to motivate student for inventing new knowledge and to improve student's thinking ability, to help students to think on their own ways, and to help student to learn well. Besides that, in mathematics teaching-learning, Kurikulum Matematika 2013 suggested that mathematical hard-skill and soft-skill such as MRA and SCM should be improved accordingly and propotionally. Those arguments suggested we had to select a kind of mathematics teaching approach so that in line with those afformentioned suggestion. One of that intended mathematics teaching approach was reciprocal teaching approach (RTA).

Some experts, Brown, S.I., Walter (2005), Brown as cited in Qohar, A., and Sumarmo (2014) expressed, that RTA was learning activities in small group which contained activities to read provided learning material, to summarize learning material, to pose question, to clarify learning material to other member, and to compile some prediction. In this RTA learning activities was chaired by student that acted as summarizer, questioner, clarifier and predictor one after another, while teacher's role was as motivator and facilitator. To observe those learning activities and student's role during RTA, writers believed that RTA would take good role on improving student's MRA and SCM.

To consider the nature of mathematics among other mathematics as a systimatic and structured science that meant mathematics content were arranged consecutively. It implied that for understanding a mathematics content well student should master its prerequisite content and process first. So, it was rational that for improving MRA of new mathematics content student should master first the previous mathematics abilities and procesess (PMA).

Recently, there were limited studies to scrunitinize student's PMA, MRA, and SCM by implementing RTA accordingly. Although, there were some studies examined student's PMA, MRA, and SCM and implemented RTA separately. For examples, there were some studies by Kurnia (2017), Yosefa (2016), Qohar, A., and Sumarmo (2014) reported advantages of RTA on enchancing various mathematical abilities and mathematical soft skills, even if, they did not analyze student's PMA, MRA, and SCM. In addition, some studies by Aminah, M., Kusumah, Y.K., Suryadi, D. and Sumarmo (2017), Nindiasari, H., Kusumah, SK., Sumarmo, U., and Sabandar (2014), Pujiastuti, H. , Kusumah, Y.S. , Sumarmo, U (2014), Setiawati (2014), Widyaningtiyas (2015) reported that PMA and various innovative teaching approaches took good roles on obtaining various mathematics hard skills and soft skills. That statement was supported by findings of studies that the higher student's grade of PMA, student obtained the higher grades of various mathematical hard skills and soft skills.

Those afformentioned arguments motivated writers to carry out a study to analyze the role of student's PMA and RTA on attaining student's MRA, SCM and then we formulated research questions as follow. 
1. Were MRA grade and its normalized gain, and SCM grade of students getting treatment with RTA better than the grades of students taught by conventional teaching for entire students and based on level of student's PMA?

2. What were student's difficulties on solving MRA tasks?

3. Was there any association between MRA and SCM?

4. Was there any interaction between PMA and teaching approaches toward student's MRA and toward student's SCM?

5. What were student's believe on RTA?

\section{Theoritical Review}

\section{Mathematical Reasoning Ability and Self Concept}

When writers visited a mathematics lesson, Basically, mathematical reasoning ability and self concept were mathematical hard-skill and soft-skill should be improved on students. There are some reason founded on that statement, among others were: a) Those hard-skill and soft skill are included in the goal of teaching mathematics (NCTM, 2000), those were: to posess logical, critical, creative, innovative thinking, and self learning abilities, and to demonstrate critical, creative, accurate, objective, opened thinking, self confidence, curious, interest, persevere, persistent attitudes; to appreciate the beauty and the usage of mathematics in daily life, and to demonstrate to like learning mathematics; b) Mathematical reasoning includes active, dynamic, generative processes that applied in solving mathematics problem and other dicipline (Schoenfeld as cited in Sumarmo (2006), and mathematical rasoning is not only to memorize facts but also for predicting and attaining meaningful understanding (Barrody, A, 1993).

Refering to opinion, Sumarmo (2010) classified two kinds of mathematical reasoning, those were inductive and deductive mathematical reasoning. Then, Sumarmo (2010) defined inductive mathematical reasoning as deriving conclussion based on observing limited data, while deductive mathematical reasoning as deriving conclussion based on definition and agreed to rules. Further Sumarmo (2010) details inductive mathematical reasoning into some kinds of reasoning, those were: a) transductive reasoning; b) Analogycal reasoning; c) Generalization; d) Predicting solution or tendency; e) Giving explanation based on model, facts, attributes, relation or pattern; f) Applying relationship of pattern for analyzing situation, and compiling conjecture.

Deductive mathematical reasoning is deriving conclussion based on agreed rules. Some of deductive mathematical reasoning activities were: a) To execute enumeration based on certain rules and principles; b) Proposisional reasoning was to reason based on the rules of inference, to examine validity of an argument, to prove and to compile valid argument; c) Proportional reasoning ability was abilty to reason based on ratio between two or more components or to compose statements concerning equality of ratio among some elements was to reason based on proportion (Leongson \& Limjap, 2003, as cited in Aminah, M., Kusumah, Y.K., Suryadi, D. and Sumarmo (2017); d) Combinatorial reasoning ability was ability to reason based on combination of some elements. Other definition, combinatorial reasoning ability is ability to combine some different variables from entirely given variables (Bernoulli as cited in Aminah, M., Kusumah, Y.K., Suryadi, D. and Sumarmo (2017); e) Probabilistic reasoning ability is ability to reason based on probability of an event. Leongson and Limjap (2003, as cited in Aminah, M., Kusumah, Y.K., Suryadi, D. and Sumarmo (2017)define probabilistic reasoning ability as ability to compare number of certain object $(n)$ from all objects $(N)$ and then to determine the chance the occurence of $\mathrm{n}$ objects from $\mathrm{N}$ objects as fraction $(n / N) ; \mathrm{f})$ Dugan (2003, as cited in Aminah, M., Kusumah, Y.K., Suryadi, D. and Sumarmo (2017)defines correlational reasoning ability is ability to correlate two separate relationships between different situations and understand that if a case happened in a situation so it will happen in other situation as well.

Considering the wideness and deepness of processes involved on mathematical reasoning, we should have to select its indicators suitable for certain level of school of students. For examples, for yunior high school students, teaching and assessment on mathematical reasoning are limited on some indicators namely: transductive, analogical, generalization and proportional reasoning, predicting, and executing enumeration based on certain rules and principles. Even though, for senior high school 


\section{Prasetio, Sumarmo, \& Sugandi, Improving Student's Mathematical Reasoning and Self Concept by Using Reciprocal Teaching}

students or university students in general we could improve and assess allmost indicators of mathematical reasoning.

When we pay closed attention on definition and indicators of MRA, allmost of them include mathematical high order thinking that for executing them an individual should have strong mathematical disposition such as high motivation, to work hard willingly, and able to manage selflearning. The strong mathematical disposition among other is self concept. Some writers defined self concept term in different expression, even if they had similar meaning and completed each other, such as viewpoint toward himself. For example, Jersild (1964) expressa. ed that self concept as viewpoint on himself and enclosed: a. Reflection of individu on self performing such as speaking ability in front of public; b. Illustration on self attribute, such as: capability and uncapabilty; self confidence, and self reliant; c. Attitudinal component namely, self esteem, and viewpoint toward his ability.

Meanings of the term of self concept in general sense were offered by some writers as follow: a. Self concept was perception, believe, feeling, or attitude of a person toward himself (Yusuf, Nurihsan (2007)); b. Self concept was viewpoint, figuring, and assessment of individu on him self, and behaviour on his progression (Symonds, as cited in Siregar (2015)); c. Self concept was person's opinion toward himself covered physic, psichology, social, emotional, aspiration, and his reached achievement (Hurlock, 1996, as cited in Pamungkas (2012), and in Siregar (2015); Self concept was vewpoint of individu on ideas, thinking, believing, and point of view on himself and those affected himself in relating to other people (Calhoun \& Acocella as cited in Desmita (2010)).

Refering to various writers' opinion, then Hendriana, H., Rohaeti, E.E., Sumarmo (2014) summarized indicator of mathematical self concept as follow: a. To point out seriousness, interest, desire, willingness, persistence in learning and doing mathematics; $b$. Able to recognize his or her strength and weakness in doing mathematics; c. Self confidence on his or her ability and success in doing mathematics task; d. Able to work together with other people; e. To appreciate other people and himself opinon; f. Having social behavior, to communicate each other and able to self position; and g. To appreciate usefullness of mathematics and point out foundness on leaning mathematics.

\section{Reciprocal Teaching Approach and Relevant Studies}

Some writers explained reciprocal teaching in different expression even if, they contained almost similar meaning. Slavin (as cited in Hendriana (2002) differentiated way of learning in reciprocal teaching approah (RTA) and in conventional learning. In RTA, student was claimed able to explain learning material which had learned independently to other member and to pose question. While in conventional teaching, to pose question was teacher's task. Other writers (Brown as cited in Suyitno, et all. 2004, Resnick, as cited in Hendriana (2002), Palincsar \& Brown as cited in Qohar, A., and Sumarmo (2014) clarified that RTA was a teaching approach which student learned in small group and excecuted some learning activities successively such as to analyze deeply available learning material, to compile a summary of the learning material, to pose question, to explain the learning material to other member of group, and to offer some prediction. To stimulate student to learn more active, learning activities during RTA was led by student one after another to act as summarizer, questioner, clarifier and predictor, while teacher acted as motivator and facilitator.

Further, Palincsar (as cited in Hendriana (2002) proposed seven steps of RTA namely: introduction, dividing role, to summarized, to pose question; to explain, to offer prediction, and clossing. Then Anggraeni (2012) clarified some advantages of RTA as follow: a. To practice student to learn self reliantly, student become more active learning; b. Learning activities was multi direction so there happen interaction among students so that student not easy to forget the formed strategy; c. Student who was hesitant to ask to teacher would be assissted by other member suitable with their roles; $d$. RTA fasilitated student to improve abilities on understanding concept, problem solving, and mathematical reasoning; e. Teacher would become more sensitive toward student's group.

Beside those advantages of RTA, there were disadvantantged as well such as: a. Student with limited capability in reading would be unpleasant and ashamed when work in small group during the lesson; b. When formatting group was not good so learning out come become not optimal; c. Limited time for discussing; $d$. When there was egoist person it caused content absorbing not optimal. 
Recently, there were limited studies that analyzed student's PMA, MRA, and SCM by implementing RTA accordingly. Although, some studies examined those research variables separately. For examples, there were few studies by Hendriana (2002), Kurnia (2017), Qohar, A., Sumarmo (2014), Yosefa (2016) reported advantages of RTA on enchancing various mathematical abilities and soft skills, even if they did not analyze student's PMA, MRA, and MCTD. Even, Sumarmo, U., Hidayat, W., Zulkarnaen, R., Hamidah, Sariningsih (2012) by using problem based learning and think talk and write strategy found that student's mathematical logical thinking ability and disposition were at low grade leve, and there was. In addition, there were some studies scrutinized student's MRA and or MSC not using RTA but conffering other innovative teaching approaches. For examples, Bernard, M. and Rohaeti, E (2016) implemented contextual teaching, Sumarni, C. and Sumarmo (2017) and Wulanmardhika (2014) rendered generative teaching approach reported that student's grades on MRA were higher than the grades of students accepted conventional teaching.

Further, some studies Aminah, M., Kusumah, Y.K., Suryadi, D. and Sumarmo(2017), Pujiastuti, H. , Kusumah, Y.S. , Sumarmo, U (2014), Setiawati (2014), Nindiasari, H., Kusumah, SK., Sumarmo, U., and Sabandar (2014), Widyaningtiyas (2015) by using various innovative teaching approaches reported that student's PMA took a good role on obtaining various student's mathematical abilities and dispositions. That statement was supported by findings that the higher student's grade of PMA, student attained higher student's various mathematical hard skills and soft skills. Those studies consentrated on very HOT mathematics abilities among other were mathematical logical thinking, reflective thinking, critical and creative thinking, proving, and problem solving, and found that many students still posed difficulties on solving those mathematical abilities.

\section{Method and Design of Study}

This study was a pretest-postest experiment control group design having a goal to analyze the role of PMA and RTA on students' mathematical reasoning ability and self concept. The study involves 72 eighth grade students, a PMA test, a MRA test, and a MSC scale. The MRA test consists of 4 items, and by using Hendriana and Sumarmo (2014) and Sumarmo (2015) as references it is obtained charactristic MRA test are as follow: reliability test is .83 (high); item validity (IV) are $.23 \leq$ IV $\leq$ .67 ; discriminat power (DP) are $.15 \leq \mathrm{DP} \leq .50$, and difficulty index (DI) are $.12 \leq \mathrm{DI} \leq .53$. In the following we attached some sample of instruments of this study.

\section{Sample 1: Item test on deductive mathematical reasoning (To solve a calculation based on certain rules and or concept)}

A water basin has a form cube with its side $1 \mathrm{~m}$. The basin is filled with water up to $\frac{1}{4}$ part of the cube. Then into the basin inserted a prism of right angle - triangle with dimension of the right sides are $30 \mathrm{~cm}$ and $40 \mathrm{~cm}$, and the height of the prism is $12 \mathrm{~cm}$.

a) Ilustrate the situation in a figure clearly.

b) Determine the increase height of water level. Write and explain the concept, and rule that used in each step of the calculation.

\section{Sample 2: Item test on mathematical reasoning (generalization)}

Observe Figure 1 of pyramid three sides, four sides, five sides, and six sides below. Suppose the process is continued up to n-sides pyramid.

Determine how many sides, how many flanks, how many points in pyramide n- sides? Explain how to ditermine your answer.

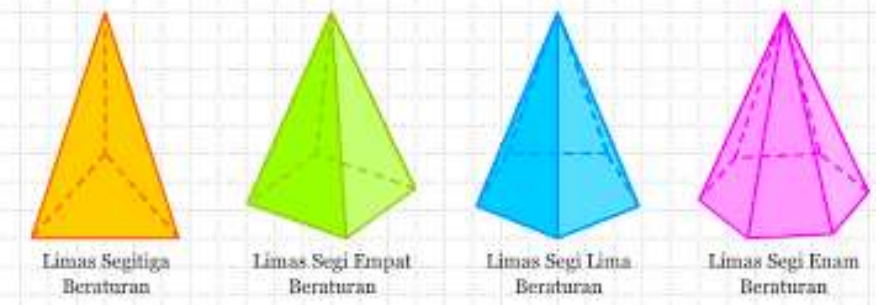

Figure 1. Several Types of Pyramid 
288 Prasetio, Sumarmo, \& Sugandi, Improving Student's Mathematical Reasoning and Self Concept by Using Reciprocal Teaching

Table 1. Sample Item of Self Concept Scale

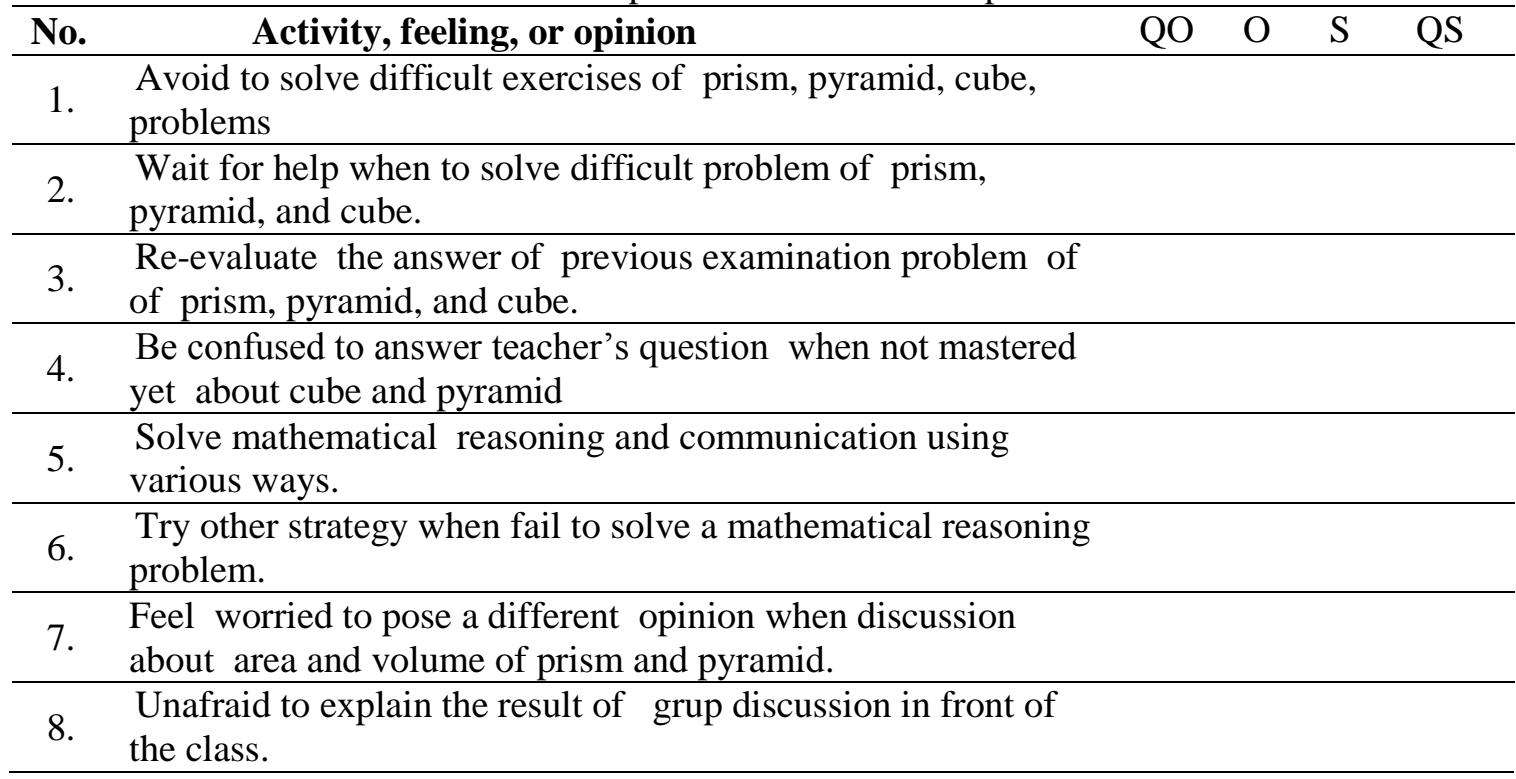

Note: QO quiet often ; O: often; S: seldom; QS: quiet seldom

\section{Findings and Discussion}

Table 2. The attaiment of MRA and its gain (N-G), and MSC of students

\begin{tabular}{|c|c|c|c|c|c|c|c|c|c|c|}
\hline \multirow[b]{2}{*}{ Variables } & \multirow[b]{2}{*}{ PAM } & \multirow{2}{*}{$\begin{array}{c}\bar{x} \\
\text { and } \\
\mathrm{S}\end{array}$} & \multicolumn{4}{|c|}{ Reciprocal Teaching } & \multicolumn{3}{|c|}{ Conventioal Teaching } & \multirow[b]{2}{*}{$\mathrm{n}$} \\
\hline & & & $\begin{array}{c}\text { Pretes } \\
(\%)\end{array}$ & $\begin{array}{c}\text { Postes } \\
(\%)\end{array}$ & $\langle g\rangle$ & $\mathrm{n}$ & $\begin{array}{c}\text { Pretes } \\
(\%)\end{array}$ & $\begin{array}{c}\text { Postes } \\
(\%)\end{array}$ & $\langle g\rangle$ & \\
\hline \multirow{8}{*}{ MRA } & High & $\bar{x}$ & $\begin{array}{c}10.00 \\
(25.64)\end{array}$ & $\begin{array}{c}31.00 \\
(79.49)\end{array}$ & .72 & \multirow[t]{2}{*}{2} & $\begin{array}{c}12.00 \\
(30.77)\end{array}$ & $\begin{array}{c}26.00 \\
(66.67)\end{array}$ & .52 & \multirow[t]{2}{*}{1} \\
\hline & & $S$ & 2.83 & 1.41 & .08 & & .00 & .00 & .00 & \\
\hline & \multirow[t]{2}{*}{ Medium } & $\bar{x}$ & $\begin{array}{c}7.33 \\
(18.80)\end{array}$ & $\begin{array}{c}25.33 \\
(64.96)\end{array}$ & .58 & \multirow[t]{2}{*}{3} & $\begin{array}{c}8.00 \\
(20.51)\end{array}$ & $\begin{array}{c}21,00 \\
(53.85)\end{array}$ & .42 & \multirow[t]{2}{*}{2} \\
\hline & & $S$ & 2,31 & 8,08 & 0,23 & & 0,00 & 4,24 & 0,14 & \\
\hline & \multirow[t]{2}{*}{ Low } & $\bar{x}$ & $\begin{array}{c}6,36 \\
(16.31) \\
\end{array}$ & $\begin{array}{c}24.80 \\
(63.59) \\
\end{array}$ & .56 & \multirow[t]{2}{*}{25} & $\begin{array}{c}7.63 \\
(19.56)\end{array}$ & $\begin{array}{c}19.44 \\
(49.86) \\
\end{array}$ & .38 & \multirow[t]{2}{*}{27} \\
\hline & & $S$ & .17 & 3.45 & .10 & & 2.72 & 5.98 & .16 & \\
\hline & \multirow[t]{2}{*}{ Total } & $\bar{x}$ & $\begin{array}{c}6.70 \\
(17.18)\end{array}$ & $\begin{array}{c}25.27 \\
(64.79)\end{array}$ & .58 & \multirow[t]{2}{*}{30} & $\begin{array}{c}7.80 \\
(20.00)\end{array}$ & $\begin{array}{c}19.77 \\
(50.68)\end{array}$ & .39 & \multirow[t]{2}{*}{30} \\
\hline & & $S$ & 1,99 & 4,11 & 0,12 & & 2,70 & 5,85 & 0,16 & \\
\hline \multirow{8}{*}{ MSC } & High & $\bar{x}$ & & $\begin{array}{r}108.50 \\
(82.20) \\
\end{array}$ & & \multirow[t]{2}{*}{2} & & $\begin{array}{c}83.00 \\
(62.88) \\
\end{array}$ & & \multirow[t]{2}{*}{1} \\
\hline & & S & & 2.12 & & & & .00 & & \\
\hline & \multirow[t]{2}{*}{ Medium } & $\bar{x}$ & & $\begin{array}{c}96.33 \\
(72.98)\end{array}$ & & \multirow[t]{2}{*}{3} & & $\begin{array}{c}80.00 \\
(60.61)\end{array}$ & & \multirow[t]{2}{*}{2} \\
\hline & & $\mathrm{S}$ & & 4,93 & & & & 1.41 & & \\
\hline & \multirow[t]{2}{*}{ Low } & $\bar{x}$ & & $\begin{array}{c}94.56 \\
(11.37)\end{array}$ & & \multirow[t]{2}{*}{25} & & $\begin{array}{c}79.70 \\
(60.38)\end{array}$ & & \multirow[t]{2}{*}{27} \\
\hline & & & & 8.61 & & & & 10.33 & & \\
\hline & \multirow[t]{2}{*}{ Total } & $\bar{x}$ & & $\begin{array}{c}95.67 \\
(72.47)\end{array}$ & & \multirow[t]{2}{*}{30} & & $\begin{array}{c}79.83 \\
(60.48)\end{array}$ & & \multirow[t]{2}{*}{30} \\
\hline & & & & 11.01 & & & & 9.80 & & \\
\hline
\end{tabular}

Note: 
MCTA: Mathematical critical thinking ability, CDM : Critical thinking disposition in mathematics
Ideal Score: 39

Ideal Score: 120

In pre-test there were no different students' grades of MRA of both class teaching approaches, and the grades were at very low level. But afther teaching approaches, the study found that RTA took better role than conventional teaching on obtaining MRA, its N-Gain, and MSC. Student getting treatment with RTA approach obtained grade of MRA was at medium level, while the grade of MSC was at fairly good level. Eventough, student accepting treatment with conventional teaching attained grades at low level on MRA and at medium levels on MSC. Testing hypothesis of those mean of mathematics learning outcomes on both teaching approaches were attached in Table 3.

Table 3. Testing Hypotesis of Mean Difference of Mathematical Reasoning ability Its N-Gain, and Self regulated learning on the Both Teaching Approcahes

\begin{tabular}{|c|c|c|c|c|c|c|}
\hline Variable & $\begin{array}{l}\text { Teaching } \\
\text { approach }\end{array}$ & $\bar{x}$ & SD & $\mathrm{N}$ & Sig. & Interpretation \\
\hline \multirow[t]{2}{*}{ MRA } & RTA & 25.27 & 4.11 & 30 & \multirow[t]{2}{*}{$.00<.05$} & \multirow[t]{2}{*}{$\mathrm{MRA}_{\mathrm{RTA}}>\mathrm{MRA}_{\mathrm{Conv}}$} \\
\hline & Conventional & 19.77 & 5.85 & 30 & & \\
\hline \multirow{2}{*}{$\begin{array}{l}\text { N-Gain of } \\
\text { MRA }\end{array}$} & RTA & .58 & .12 & 30 & \multirow[t]{2}{*}{$.00<.05$} & \multirow{2}{*}{$\begin{array}{c}\text { N-Gain MRA }_{\text {RTA }}> \\
\text { N-Gain MRA }_{\text {Conv }}\end{array}$} \\
\hline & Conventional & .39 & .16 & 30 & & \\
\hline \multirow[b]{2}{*}{ MSC } & RTA & 95.67 & 11.01 & 30 & \multirow[b]{2}{*}{$.00<.05$} & \multirow[b]{2}{*}{$\operatorname{MSRL}_{\mathrm{RTA}}>\mathrm{MSRL}_{\mathrm{Conv}}$} \\
\hline & Conventional & 79.83 & 9.80 & 30 & & \\
\hline
\end{tabular}

Note: MRA : mathematical reasoning ability

MSC : mathematical self concept
Ideal score MRA: 39

Ideal score MSC :132

The finding of the grades of MRA at medium level were almost similar to the findings of previous studies that students getting treatment with various innovative teaching that attained grades at fairly good level (Bernard, M. and Rohaeti, E (2016), Mulyana, A. and Hendriana (2015), Sumarni, C. and Sumarmo (2017). But in other studies by Aminah, M., Kusumah, Y.K., Suryadi, D. and Sumarmo (2017), Rohaeti, E.E., Budyanto, A.M., Sumarmo (2014), Rosliawati (2014), Setiawati (2014), Wulanmardhika (2014) students' grades on MRA were at low-medium level. Seemingly, innovative teaching mathematics gave different result on students' grades of MRA from low level up to good level, while students taught by conventional teaching tended to obtain MRA at low level. The low students' grades on MRA were found on studies with senior high school students and on intermediate mathematics course such as system of equation of two and more variables, (Aminah, M., Kusumah, Y.K., Suryadi, D. and Sumarmo (2017), Setiawati (2014). While for almost students getting treatment with conventional teaching, students' grades on MRA tended at low level.

In further analysis, by using contigency table and statistic Pearson-Chi Square $\left(\chi^{2}\right)$ the study found that $\chi^{2}=4.286^{\mathrm{a}}, \mathrm{C}=.313$, and $\mathrm{sig}=.576>.05 \mathrm{It}$ meant that there was no association between MRA and MSC.

Table 4. Contigency Table of Mathematical Reasoning Ability and Mathematical Self Concept

\begin{tabular}{ccccc}
\hline MSC & \multirow{2}{*}{ High } & Medium & Low & Total \\
\hline MRA & 5 & 0 & 1 & 6 \\
\hline High & 14 & 6 & 1 & 21 \\
\hline Ledium & 3 & 0 & 0 & 9 \\
\hline Total & 22 & 6 & 2 & 30 \\
\hline
\end{tabular}

Table 5. Test of Pearson-Chi Square and Contigency Coefficient between Mathematical Reasoning Ability and Mathematical Self regulated learning 
290 Prasetio, Sumarmo, \& Sugandi, Improving Student's Mathematical Reasoning and Self Concept by Using Reciprocal Teaching

\begin{tabular}{cccc}
\hline $\begin{array}{c}\text { Pearson-Chi } \\
\text { Square }\left(\chi^{2}\right)\end{array}$ & DF & $\begin{array}{c}\text { Contigency } \\
\text { Cofficient }(C)\end{array}$ & Sig.(2-tailed) \\
\hline $4.286^{\mathrm{a}}$ & 4 & .313 & $.576>.05$ \\
\hline
\end{tabular}

The next analysis was about intraction between PMA and teaching approaches (RTA and conventional teaching) toward MRA and MSC. The analysis using two path Anova as on Table 6 and Table 7, and was completed with graph those interaction as in Figure 1 and Figure 2.

Table 6. Two Path Anova between PAM and Teaching Approaches toward MRA

\begin{tabular}{llllll}
\hline Source & $\begin{array}{l}\text { Type III Sum } \\
\text { of Squares }\end{array}$ & Df & $\begin{array}{l}\text { Mean } \\
\text { Square }\end{array}$ & F & Sig. \\
\hline Corrected Model & $569.650^{\mathrm{a}}$ & 5 & 113.930 & 4.506 & .002 \\
\hline Intercept & 9035.624 & 1 & 9035.624 & 357.366 & .000 \\
\hline KAM & 105.541 & 2 & 52.770 & 2.087 & .134 \\
\hline Pembelajaran & 89.515 & 1 & 89.515 & 3.540 & .065 \\
\hline KAM * Pembelajaran & 1.194 & 2 & .597 & .024 & .977 \\
\hline Error & 1365.333 & 54 & 25.284 & & \\
\hline Total & 32355.000 & 60 & & & \\
\hline Corrected Total & 1934.983 & 59 & & & \\
\hline
\end{tabular}

Table 7. Two Path Anova between PAM and Teaching Approaches toward MSC

\begin{tabular}{llllll}
\hline Source & $\begin{array}{l}\text { Type III Sum of } \\
\text { Squares }\end{array}$ & Df & Mean Square & F & Sig. \\
\hline Corrected Model & $4132.294^{\mathrm{a}}$ & 5 & 826.459 & 7.527 & .000 \\
\hline Intercept & 121918.690 & 1 & 121918.690 & 1110.416 & .000 \\
\hline KAM & 190.047 & 2 & 95.024 & .865 & .427 \\
\hline Pembelajaran & 1333.286 & 1 & 1333.286 & 12.143 & .001 \\
\hline KAM * Pembelajaran & 72.847 & 2 & 36.423 & .332 & .719 \\
\hline Error & 5928.956 & 54 & 109.795 & & \\
\hline Totalbetween & 472065.000 & 60 & & & \\
\hline Corrected Total & 10061.250 & 59 & & & \\
\hline
\end{tabular}

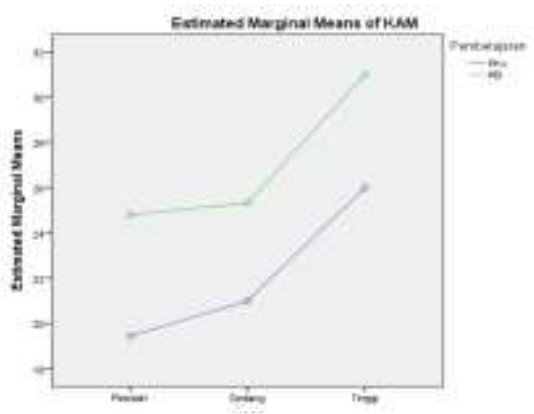

Figure 1

Graph of Interaction between PAM and Teaching Approaches on MRA

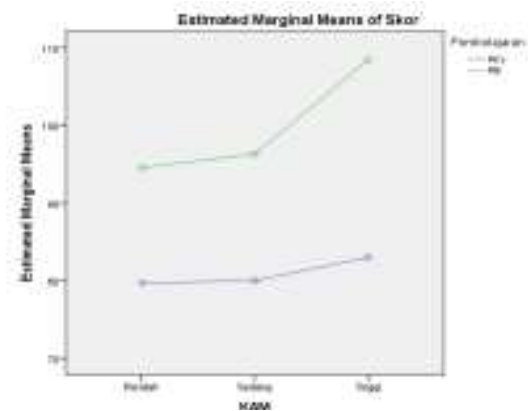

Figure 2

Graph of Interaction between PAM and Teaching Approaches on MSC

Based on Table 6, Tabel 7, conventional teaching and student's PMA. Further analysis was concerned with student's difficulties on solving mathematical reasoning tasks. The data were illustrated in Table 6.

Table 6. Mean Score Of Each Item Of Mathematical Reasoning Ability Test of Students In Both Teaching Approaches 


\begin{tabular}{cccccc}
\hline Teaching & Stat.Desc & No.1 & No 2. & No.3 & No.4 \\
\cline { 2 - 6 } approach & Ideal score & $\mathbf{8}$ & $\mathbf{6}$ & $\mathbf{1 0}$ & $\mathbf{1 5}$ \\
\hline Reciprocal & $\overline{\bar{x}}$ & 5,84 & 5,60 & 5,36 & 8,00 \\
\cline { 2 - 6 } Teaching & $\%$ out of IS & 73,00 & 93,33 & 53,60 & 53,33 \\
\hline Conventional & $\bar{x}$ & 5,07 & 5,20 & 5,33 & 4,17 \\
\cline { 2 - 6 } Teaching & \% out of IS & 63,38 & 86,67 & 53,30 & 27,80 \\
\hline
\end{tabular}

The study found that many students of RTA and conventional teaching attained at low grades (less than $60 \%$ out of ideal score) on 2 items of MRA test those were about generalization and to excecute calculation based on agreed to principle and rules. This finding was different with findings of other previous studies Bernard, M. and Rohaeti, E (2016), Rohaeti, E.E., Budyanto, A.M., Sumarmo (2014), Setiawati (2014), Sumarni, C. and Sumarmo (2017), Wulanmardhika (2014) that students obtained at low grades on MRA.

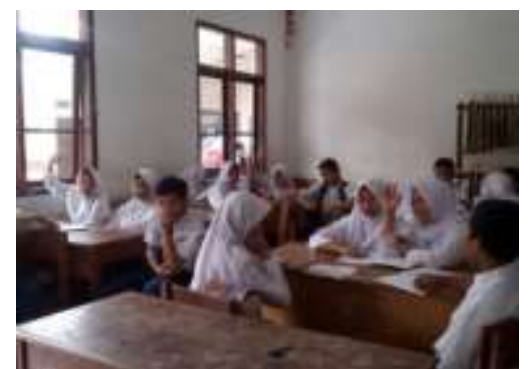

Figure 3

Student pose question in Reciprocal Teaching Approach

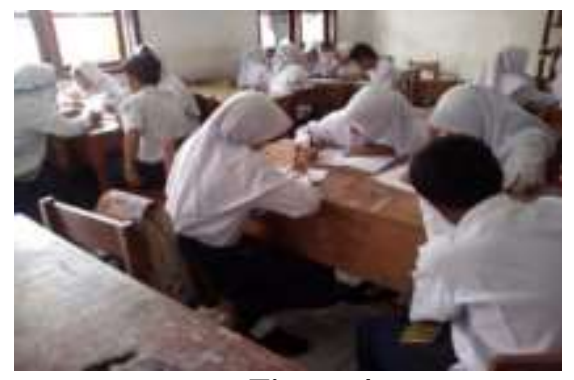

Figure 4

Students work in smal group in Reciprocal Teaching Approach

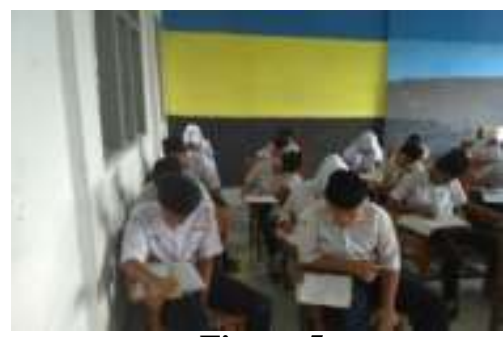

Figure 5

Student work individually in conventional teaching

Besides those findings, this study also found that students demonstrated more active learning during Reciprocal Teaching compared to student's activities during conventional teaching. They discussed actively in small group, to indentify problem on the students' work sheet (Figure 1) and (Figure 2). While, in the conventional teaching student less active learning and they work individually (Figure 3). Moreover, students expressed positive opinion on RTA. Students tended to be comfortable with the new accepted teaching approach (RTA), despite at first they were confused to solve new kind mathematics problems. In this study, sometimes teacher faced obstruction in conducting RTA, such as limitted allocated time whereas it needed long time for students to construct their knowledge, to discuss in their group, and to present their solution in front of the class. Eventhough, in further sesions the obstruction could be handled by offering more interesting mathematics task and guidance during students working together in each small group.

\section{Conclusion and Suggestion}

Based on study finding and discussion, it derived some conclussion as follow. Reciprocal Teaching Approach and prior mathematics ability gave better role than conventional teaching on improving students' mathematical reasoning ability, its gain, and mathematical self concept as well. Students getting treatment with Reciprocal Teaching Approach obtained at medium grade level on mathematical reasoning ability, while students taught by conventional teaching attained at rather low 
292 Prasetio, Sumarmo, \& Sugandi, Improving Student's Mathematical Reasoning and Self Concept by Using Reciprocal Teaching

grade level. Even if students in both teaching approaches still realized difficulties in solving generalization and carry out enumeration based on agreed principles and rules. On mathematical self concept students getting treatment with Reciprocal Teaching Approach obtained better grade than that of students taught by conventional teaching, and those grades were at fairly good and medium level.

The other conclussion were there were no association between mathematical reasoning ability and mathematical self concpet, and there were no interaction between prior mathematics abilitiy and teaching approaches (reciprocal teaching approach and conventional teaching toward mathematical reasoning ability and toward mathematical self concept. In addition, students getting treatment with reciprocal teaching performed more active learning than student taught by conventional teaching. Like that, student posed positive opnion on reciprocal teaching approach.

In this study, most of students did not master yet prior mathematics ability, so that students obtained mathematical reasoning grade at medium level and they still realized some difficulties in solving mathematical reasoning task. So, writers suggested that students should be strengthened their prior mathematics ability and gave them more excercises on generalization task and asked them to write principles and rules used in every step of solving mathematics problem.

In order to students to attain better grade on mathematical self concept, it is suggested four ways as follow Sauri (2015): Be aware to students on the meaning and the importance of having good mathematical self concept attitude; Teacher should performed having behavior of wished mathematical self concept attitude; Familiarize students to behave the wished mathematical self concept attitude; Carry out integrated and continous mathematics teaching-learning process.

\section{REFERENCES}

Aminah, M., Kusumah, Y.K., Suryadi, D. and Sumarmo, U. (2017). Enhancing Students' Mathematical Logical Thinking Ability and Self Regulated Learning By Using Metacognitive Teaching-Learning. Paper Published in International Journal of Instruction, 11(3).

Anggraeni, Y. (2012). Meningkatkan Kemampuan Penalaran dan Komunikasi Matematis Siswa SMP Melalui Reciprocal Teaching. Jurnal Pendidikan Matematika.

Barrody, A, J. (1993). Problem Solving, Communication, and Communicating, (K-8): Helping Children Think Mathematically. New York: Merill as imprint of Macmillan Publishing Company.

Bernard, M. and Rohaeti, E, E. (2016). Meningkatkan Kemampuan Penalaran dan Disposisi Matematik Siswa SMK dengan Pendekatan Kontekstual melalui Game Adobe Flash Cs 4.0. Edusentris: Jurnal Ilmu Pendidikan Dan Pengajaran, 3(1), 85-94.

Brown, S.I., Walter, M. . (2005). The Art of Problem Posing. London: Lawrence Erlbaum Associates.

Desmita. (2010). Psikologi Perkembangan Peserta Didik: Panduan Bagi Orang Tua dan Guru dalam Memahami Psikologi Anak Usia SD, SMP, dan SMA. Bandung: Remaja Rosdakarya.

Hendriana, H., Rohaeti, E.E., Sumarmo, U. (2014). Hard Skill dan Soft Skill Mathematika. Bandung: Refika Aditama.

Hendriana, H. (2002). Meningkatkan Kemampuan, Pengajuan dan Pemecahan Masalah Matematika dengan Pembelajaran Berbalik Studi Eksperimen pada Siswa Kelas I SMU Negeri 23 Kota Bandung. Bandung: Unpublished Thesis at Post Graduate Study UPI.

Jersild, A. T. (1964). When Teachers Face Themselves. New York: McGraw-Hill Book Company.

Kurnia, A. (2017). Mengembangkan Kemampuan Pemahaman dan Komunikasi serta Kemandirian Belajar Matematik Siswa SMP melalui Pendekatan Reciprocal Teaching. Bandung: Unpublished Thesis at Post Graduate Study STKIP Siliwangi.

Mulyana, A. and Hendriana, H. (2015). Meningkatkan Kemampuan Komunikasi dan dan Kemandirian Belajar Matematika Siswa SMP melalui Pembelajaran Berbasis Masalah. Edusentris, Jurnal Ilmu Pendidikan Dan Pengajaran, 2(3).

NCTM. (2000). Principles and Standards for School Mathematics. USA: NCTM.

Nindiasari, H., Kusumah, SK., Sumarmo, U., and Sabandar, Y. (2014). Pendekatan metakognitif untuk meningkatkan kemampuan berpikir Reflektif Matematis Siswa SMA. Edusentris Jurnal Ilmu Pendidikan Dan Pengajaran, 1(1), 80-90.

Nurihsan, J. (2007). Materi Pokok Perkembagan peserta Didik. Bandung: UPI. 
Pamungkas, A. S. (2012). Pembelajaran Eksplorasi untuk Mengembangkan Kemampuan Berpikir Logis dan Self Concept Matematis Mahasiswa Sekolah Menengah Pertama. Bandung: Tesis UPI: Tidak diterbitkan.

Polya, G. (1980). On Solving Mathematical Problems in High School. New Jersey: Princeton Univercity Press.

Pujiastuti, H. , Kusumah, Y.S. , Sumarmo, U, A. J. D. (2014). Pujiastuti, H. , Kusumah, Y.S. , Sumarmo, U, Afgani J. D (2014). "Inquiry Cooperation Model Enchanching Yunior High School Students' Mathematical Problem Solving Ability" Paper published in International Journal of Contemporary Educational Research. (IJCE. Paper Published in International Journal of Contemporary Educational Research (IJCER), 1(1).

Qohar, A., and Sumarmo, U. (2014). Improving Mathematical Communication Ability and Self Regulation Learning Of Yunior High Students by Using Reciprocal Teaching. Journal on Mathematics Education, 4(1).

Qohar, A., Sumarmo, U. (2014). Improving Mathematical Communication Ability and Self Regulated Learning Of Yunior High Students by Using Reciprocal Teaching. Journal on Mathematics Education, 4(01), 59-74.

Rohaeti, E.E., Budyanto, A.M., Sumarmo, U. (2014). Enhanching Students' "Mathematical Logical Thinking Ability and Self-Regulated Learning Through Problem Based Learning." International Journal of Education, 8(1), 54-63.

Rosliawati, I, S. E. (2014). Mengembangkan Kemampuan Penalaran dan Komunikasi serta Disposisi Matematik Siswa SMP melalui Pembelajaran Berbasis Masalah. Bandung: Unpublished Thesis at Post Graduate Study STKIP Siliwangi.

Sauri, S. (2015). Membangun Karakter Bangsa melalui Pembinaan Profesionalisme Guru Berbasis Pendidikan Nilai. Jurnal Pendidikan Karakter, 2(2), 1-15.

Setiawati, E. (2014). Mengembangkan Kemampuan Berpikir Logis, Kreatif, dan Habits of Mind Matematis melalui Pembelajaran Berbasis Masalah. Bandung: Unpublished Disertation at Post Graduate UPI.

Shadiq, F. (2004). Pemecahan Masalah, Penalaran, dan Komunikasi. Yogyakarta: PPPG Matematika.

Siregar, H. M. (2015). Kemampuan Berpikir Kreatif Matematis dan Self Concept Siswa Sekolah Menengah Pertama. Bandung: UPI: Tidak diterbitkan.

Sumarmo, U., Hidayat, W., Zulkarnaen, R., Hamidah, Sariningsih, R. (2012). Kemampuan dan Disposisi Berpikir Logis, Kritis, Dan Kreatif Matematis: Eksperimen terhadap Siswa SMA Menggunakan Pembelajaran Berbasis Masalah dan Strategi Think-Talk-Write. Jurnal Pengajaran MIPA, 17(1), 17-33.

Sumarmo, U. (2006). Kemandirian belajar: Apa, mengapa dan bagaimana dikembangkan pada peserta didik" Paper presented at Seminar of Mathematics Education in Department of Mathematics, Faculty of Mathematics and Science, State University of Yogyakarta. Makalah dimuat dalam Sur. Bandung: Jurusan Pendidikan Matematika FPMIPA UPI.No Title.

Sumarmo, U. (2010). Berpikir dan Disposisi Matematik: Apa, Mengapa, dan Bagaimana Dikembangkan pada Peserta Didik". [Online]. in http://www.docstoc.com/docs/ 62326333/Pembelajaran-Matematika. [5 Maret 2012]. Paper published in Sumarmo, U. (2013) and Suryadi, D. Turmudi, Nurl. Bandung: Jurusan Pendidikan Matematika FPMIPA UPI.No Title.

Sumarni, C. and Sumarmo, U. (2017). Penalaran Matematik dan Kemandirian Belajar: Eksperimen terhadap Siswa SMP melalui Pembelajaran Generatif. Edusentris: Jurnal Ilmu Pendidikan Dan Pengajaran, 3(1), 290-299.

Suparno, P. (1997). Filsafat Konstruktivisme dalam Pendidikan. Yogyakarta: Kanisius.

Widyaningtiyas, R. (2015). Pengaruh Pendekatan Pembelajaran Berbasis Masalah terhadap Kemampuan dan Disposisi Berpikir Kritis dan Kreatif Matematis Siswa SMA. Part of Disertation, that is: Widyaningtias,R., Kusumah, Y.S., Sumarmo, U. Sabandar, Y. (2017), "The Impact of Problem Base. Journal of Mathematics Education, 6(2), 107-116.

Wulanmardhika, M. (2014). Meningkatkan Kemampuan Pemahaman, Penalaran, dan Disposisi Matematik Siswa SMA melalui Pembelajaran Generatif. Bandung: Unpublished Thesis at Post Graduate Study of Indonesia University of Education. 
294 Prasetio, Sumarmo, \& Sugandi, Improving Student's Mathematical Reasoning and Self Concept by Using Reciprocal Teaching

Yosefa. (2016). Pembelajaran Terbalik untuk mengembangkan kemampuan berpikir kreatif dan komunikasi matematis serta kemandirian belajar siswa SMA. Bandung: Tesis pada Pascasarjana STKIP Siliwangi Bandung: tidak dipublikasikan.

Yusuf, S. (2007). Psikologi Perkembangan Anak \& Remaja. Bandung: Remaja Rosdakarya. 